\title{
Design, Construction and Performance Evaluation of a Melon Seeds Sheller
}

\author{
Sobowale SS ${ }^{1 *}$, Adebiyi $\mathrm{JA}^{1,2}$ and Adebo $\mathrm{OA}^{1,2}$
}

${ }^{1}$ Department of Food Technology, Moshood Abiola Polytechnic, P. M. B. 2210, Abeokuta, Ogun State, Nigeria

${ }^{2}$ Department of Biotechnology and Food Technology, University of Johannesburg, P. O. Box 17011, Doornfontein 2028, Johannesburg, South Africa

\begin{abstract}
Melon seed is an important oil seed crop that serves numerous food purposes. Shelling of this crop is vital, prior to its vast applications. To address the challenges associated with shelling melon, a design for shelling melon seeds on a small scale was presented and evaluated. Parameters evaluated include shelling efficiency, percentage seed shelled and damaged, throughput and machine capacity. The machine was constructed using locally available materials and consists of a hopper, frame, shelling and cleaning unit, chutes and prime mover. Shelling operation was carried using melon seeds of three different moisture contents $(6.99,11.90$ and $18.32 \%)$ and at different shelling speeds of 2500 and $1500 \mathrm{rpm}$, while performance evaluation were evaluated. Results obtained showed that shelling speed of $1500 \mathrm{rpm}$ and moisture content of $18.32 \%$ has the best shelling efficiency of $76.30 \%$ and least percentage seed damage of $22.60 \%$, compared to shelling speed of 2500 rpm and seed moisture content of $6.99 \%$, which had a shelling efficiency of $70.0 \%$ and percentage seed damage of $68.10 \%$. Shelling speeds of the machine and seed moisture content of melon affects the rate, efficiency and percentage seed damage. The machine and throughput capacity of the equipment are 7.95 and $9.56 \mathrm{~kg} / \mathrm{h}$, respectively. This design and set of conditions selected were the most preferred because of the low cost, rapid operation, lesser seed damage and minimal human energy expenditure. The melon seed sheller is user friendly, does not require skilled labor and independent from any central electric power supply. The equipment design was found suitable for rural development.
\end{abstract}

Keywords: Melon; Shelling; Seed damage; Performance evaluation; Efficiency

\section{Introduction}

Melon (Colocynthiscitrullus.L.) is an extensively cultivated and consumed oil seed crop in Nigeria and West Africa [1,2]. As reported by Aguayo, it is the fourth most important crop in the world in terms of production (18 metric tons), after orange, banana and grape [3]. These seeds are vastly nutritious, furnishing the human diet with good quality proteins [4]. It contains about $41.51 \%$ essential amino acids and other essential nutrients [5-7]. Melon seed is also a good source of minerals, vitamins, oil and energy in form of carbohydrates [8]. The seed contains 0.6 proteins, $4.6 \mathrm{~g}$ carbohydrates, $33 \mathrm{mg}$ vitamin C, $0.6 \mathrm{~g}$ crude fiber, 230 mg K, 16 mg P, $17 \mathrm{~g}$ Ca per $100 \mathrm{~g}$ edible seeds and unsaturated fatty acids [9]. According to Bankole, it is grown mainly for the intended use of its shelled kernel. This can be sprinkled into a soup or stew and can also be grounded into a thick paste. It is also transformed into products such as 'ogiri', baby 'robo cake', livestock feed, while its oil is used in the production of soap and local pomade [10,11].

The processing of melon is imperative to further diversify its use. This includes shelling, washing, coring, drying, fermentation, drying and oil extraction. Shelling involves removing the outermost part (husk) from the melon kernel. Here, the seed is separated from the spiny husk. This operation can be carried out in the field or at the storage environment [12]. Shelling of melon as a unit operation is therefore an important step towards the processing of melon to its finished products. Most acreage farmers, who cultivate this crop in Nigeria and West Africa alike, encounter several processing challenges of shelling, as it requires a relatively high expenditure of human energy which is a major concern.

The inability to effectively shell melon in order to meet the requisite capacity necessary for industrial utilization, has been a hindrance to its use for large scale production of various commodities [13]. The conventional, traditional or manual method of shelling melon is inefficient, tedious and time consuming, thus limiting the availability of their products in the market $[14,15]$. Furthermore, these obsolete methods results in bruising and serious injury to the human fingers, coupled with low output rates [16]. Thus the quest for a satisfactory, cheap and effective means such as mechanized shelling technique is of importance, for small and medium scale farmers in Nigeria. Different forms and types of melon shellers exist, according to their source of power, and can thus be classified as electrically powered or fuel-driven melon shellers. However, with the prevalence of the erratic power supply, which is synonymous with Nigeria, it is imperative to look for other means of powering equipment. Fuel-powered sheller is a better choice and has advantages over the electrical powered one such as its availability, either in the presence or absence of electric power supply and also non-reliance on electricity.

Different studies have been done on the design and development of shellers [17-19]. But not much work has been done in the literatures on the design and construction of a mechanized fuel-powered melon sheller. Therefore, the need for a more cost effective, simple, friendly, hygienic and technologically feasible system for shelling melon remains imperative. Hence, the objectives of this work are to design and construct a fuel powered melon sheller and to evaluate the performance of the constructed melon shelling machine.

\section{Materials and Methodology}

\section{Materials}

The materials used for the construction of the melon sheller

*Corresonding author: Sobowale SS, Department of Food Technology, Moshood Abiola Polytechnic, P. M. B. 2210, Abeokuta, Ogun State, Nigeria, Tel: 2348033791755; E-mail:sobowale.sam@gmail.com

Received April 14, 2015; Accepted May 14, 2015; Published May 21, 2015

Citation: Sobowale SS, Adebiyi JA, Adebo OA (2015) Design, Construction and Performance Evaluation of a Melon Seeds Sheller. J Food Process Technol 6: 463. doi:10.4172/2157-7110.1000463

Copyright: (c) 2015 Sobowale SS, et al. This is an open-access article distributed under the terms of the Creative Commons Attribution License, which permits unrestricted use, distribution, and reproduction in any medium, provided the original author and source are credited. 


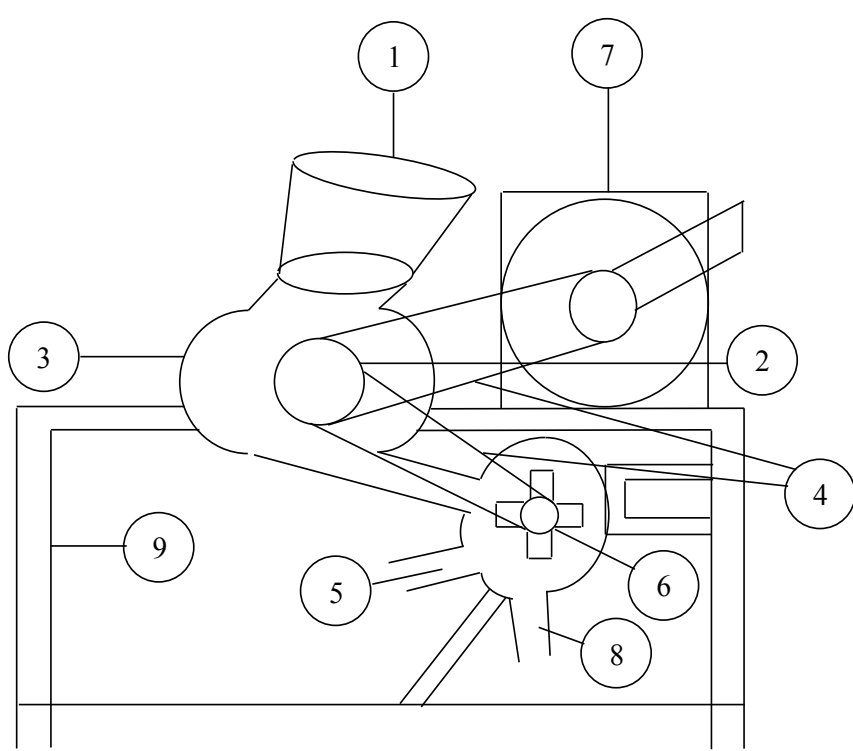

Figure 1: Sketch and line diagram of the melon sheller; 1 - Hopper; 2 - Pulley; 3 - Shelling disc; 4 - Belt; 5 - Outlet for melon shells (chaff); 6 - Blower/Fan; 7 - Prime mover; 8 - Outlet for shelled melon; 9 - Frame/Stand.

include: mild steel, ball bearings, angle iron, static disc, electrode, single and double groove pulley, shaft and belt. The design of the melon sheller showing all the internal component of the machine is as shown in Figure 1. The melon seeds used to evaluate the performance of the machine were purchased from a local market in Abeokuta $\left(7.15^{\circ} \mathrm{N}\right.$, $3.35^{\circ} \mathrm{E}$ ), Nigeria. The samples were cleaned to remove debris and foreign materials.

\section{Design considerations}

A machine should not be only technically correct and operated as predicted, but it should be capable of performing the purpose of the proposed application. It is however expedient that a melon sheller apart from effectively performing its proposed application, it should also satisfy process requirement throughout its service life and incorporate the design features of durability and hygiene. The following factors were also considered in the design of the melon seed sheller: (i) availability of raw materials for construction; (ii) mechanical properties of the material; (iii) cost (iv) power requirement; (iv) ease of fabrication and dismantling.

\section{Design computations}

The significant properties of melon seed ,influenced the basic design of this machine[20]. Basic considerations were given to the design for the capacity and size of the machine, power requirement, speed of the pulley, length of the belt, diameter of the shaft. Equations $(1-9)$, were used to calculate some of the parameters for the various components of the sheller [21-24].

$$
\begin{aligned}
& V=1 / 3 \pi r^{2} h \\
& M=\rho \times V \\
& W=M g \\
& d^{3=} 16 / \bar{\wedge}_{S_{s}} \sqrt{\left(M_{t} K_{t}\right)^{2}+\left(M_{b} K_{b}\right)^{2}} \\
& N_{1} D_{1}=N_{2} D_{2} \\
& V_{1}=\pi D_{1} N_{1} / 60 ; V_{1=} V_{2} \text { since there is no slip. }
\end{aligned}
$$

$$
\begin{aligned}
& L=2 C+\pi / 2\left(D_{1}+D_{2}\right)+\left(D_{1}-D_{2}\right)^{2} / 4 \mathrm{C} \\
& C=\left(D_{2}+D_{1}\right) / 2+D_{1} \\
& T=P \times 60 / 2 \pi N
\end{aligned}
$$

where; $\mathrm{V}=$ volume of the hopper $\left(\mathrm{m}^{3}\right) ; \pi=3.142 ; \mathrm{r}=$ radius $(\mathrm{m})$; $\mathrm{h}=$ height $(\mathrm{m}) ; \mathrm{M}=$ mass of melon seeds $(\mathrm{Kg}) ; \rho=$ Density of melon seed $\left(\mathrm{Kg} / \mathrm{m}^{3}\right)$; $\mathrm{W}=$ weight $(\mathrm{N}) ; \mathrm{M}=$ mass $(\mathrm{Kg}) ; \mathrm{g}=$ acceleration due to gravity $\left(9.81 \mathrm{~m} / \mathrm{s}^{2}\right) ; \mathrm{d}=$ diameter of the shaft $(\mathrm{m}) ; \mathrm{M}_{\mathrm{b}}=$ Bending moment $(\mathrm{Nm})$; $\mathrm{M}_{\mathrm{t}}=$ Torsional moment $(\mathrm{Nm}) ; \mathrm{K}_{\mathrm{b}}=$ combined shock and fatigue factor applied to bending moment; $\mathrm{K}_{\mathrm{t}}=$ combined shock and fatigue factor applied to torsional moment; $\mathrm{S}=$ =allowable shear stress; $\mathrm{N}_{1=}$ speed of the driving motor (driver) (rpm) $\mathrm{D}_{1=}$ diameter of the driving pulley $(\mathrm{mm})$ $\mathrm{N}_{2=}$ speed of the shaft (driven) (rpm) $\mathrm{D}_{2=}$ diameter of the driven pulley $(\mathrm{mm}) ; \mathrm{V}_{1-}$ speed of the driving pulley $(\mathrm{m} / \mathrm{s}) ; \mathrm{V}_{2}=$ speed of the driven pulley $(\mathrm{m} / \mathrm{s}) ; \mathrm{L}=$ Belt length $(\mathrm{mm}) ; \mathrm{C}=$ Centre distance $(\mathrm{mm}) ; \mathrm{T}=$ torque (Nm); $\mathrm{P}=$ power of motor (W); $\mathrm{N}=$ revolutions per minute (rpm). From the design calculations, the $0.0089 \mathrm{~m}^{3}$ hopper can hold $7.40 \mathrm{~kg}$ of melon seed. Using equation 4 , the minimum diameter of the shaft obtained was $13 \mathrm{~mm}$. However, to allow for safety factor, an optimum shaft diameter of $15 \mathrm{~mm}$ was used, to overcome load on the shaft. Diameter of the driven pulley was calculated as $71 \mathrm{~mm}$, with a speed of $9.23 \mathrm{~m} / \mathrm{s}$. The belt length required was calculated as $457 \mathrm{~mm}$ and the torque of the machine is $13.33 \mathrm{Nm}$.

\section{Construction and description of the machine}

The pictorial view of the constructed melon sheller was shown in Figure 2. Locally available, but quality materials (mild steel, angle iron, pulleys, shaft, belts and motor) which produce the desired objective at minimum cost were used. The machine consists of the hopper, shelling unit (which consists of rotating disc and static disc), the frame, the cleaning unit and chutes. To facilitate free flow of seeds into the shelling unit, the conical shaped hopper was fabricated using mild steel into a height of $200 \mathrm{~mm}$, upper radius of $200 \mathrm{~mm}$ and lower radius of $50 \mathrm{~mm}$ and inclined at an angle of $120^{\circ}$. The shelling unit consists of the rotating and static discs, vanes and the shelling drum. The outer part of the rotating disc is lined with flat metal blades ( $3 / 4$ inch) of $50 \mathrm{~mm}$ length were welded at an angle of $60^{\circ}$, and were arranged side by side with a distance of $10 \mathrm{~mm}$ between the blades, along the diameter (150 $\mathrm{mm}$ ) of the disc, forming vane slots at the edges of the rotating disc. The static disc consists of flat metal rods of $120 \mathrm{~mm}$ length, arranged side by side and welded at a distance of $10 \mathrm{~mm}$ to each other at an angle of $60^{\circ}$ along the walls of the fixed drum which formed spikes. The frame which is the support on which the whole unit rests, was made from angle iron into a rectangular of size $920 \mathrm{~mm} \times 256 \mathrm{~mm} \times 730 \mathrm{~mm}$ high.

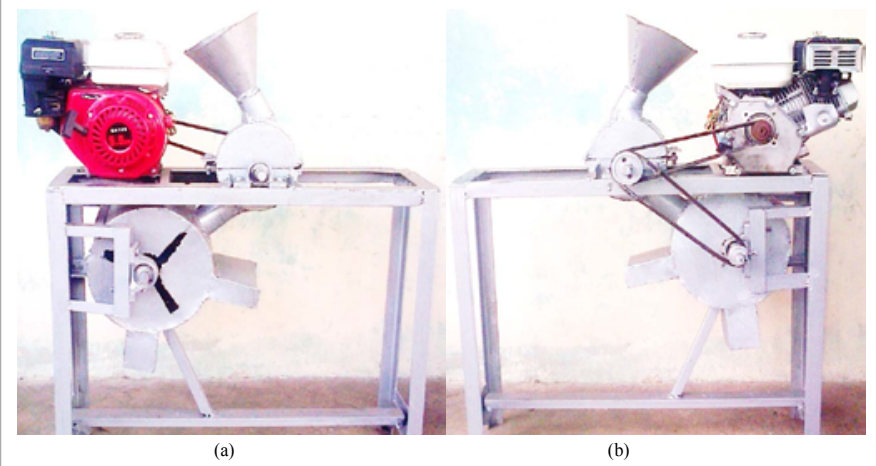

Figure 2: Pictorial view of the melon sheller: (a) right side and (b) left side. 
The cleaning unit is to facilitate the separation of the shelled melon seeds from the chaff. The cleaning unit consists of mild steel folded and welded to form a chute of $350 \mathrm{~mm} \times 50 \mathrm{~mm} \times 40 \mathrm{~mm}$, length, width and height respectively. A regulated fan was installed at one end of the tunnel to supply air to separate the chaff from the cotyledon after shelling. Power was supplied by a $5.5 \mathrm{Hp}$ gasoline engine and transmitted to the machine through the use of pulleys, belts and shaft.

\section{Operation}

To operate the machine, appropriate quantity of fuel (gasoline) and engine oil was correctly measured into the fuel and oil tanks, respectively. The prime mover was started and left to operate for few minutes to enable the machine attain its operational speed. About 5 $\mathrm{kg}$ of melon seeds were fed in through the hopper continuously but gradually. The seeds flowed through the lower opening of the hopper onto the vanes into the shelling unit. In the shelling unit, the melon seeds were thrown against the wall of the shelling drum and the rotating vanes. Through impact of the shelling vanes, walls of the shelling drum, and collision of the seeds with each other, the shells were weakened and subsequently broke. After the shelling process, both mixture of the seeds and chaff fell through a chute, leading to the cleaning unit. In the cleaning unit, a fixed regulated fan separated the shelled seeds from the chaff, by air current. The denser shelled seeds fell through a discharge outlet, while the chaff was blown through a chute opposite the fan. The dimensioning and design parameters were done in accordance to standard engineering practices.

\section{Performance evaluation}

The performance evaluation of the machine was done with a $5.5 \mathrm{Hp}$. prime mover, using melon seeds of three different moisture contents. The untreated seeds; seeds soaked for 12 hours and sun dried; and seeds sprinkled with water and partially dried with natural air for 10 minutes. The moisture contents of these samples were determined using the methods of AOAC (2004), just before the shelling operation as given in Table 1 . This was done because the moisture content of the seeds varies according to place, variety, season, time of harvest and processing. The melon shelling machine was fed with a known initial quantity of melon seeds (N0) and the shelling experiments were performed using the following variables as shown in Table 1 .

After each experiment, the seeds were carefully collected from the outlets and divided into shelled-unbroken seeds (N1), shelled-broken seeds (N2), partially shelled seeds (N3), unshelled seeds (N4), unshelled seeds but broken (N5) and subsequently weighed. Percentages of shelled unbroken-seeds $\left(\eta_{\mathrm{s}}\right)$, broken seeds $\left(\eta_{\mathrm{b}}\right)$, partially shelled seeds $\left(\eta_{\mathrm{p}}\right)$ and unshelled seeds $\left(\eta_{\mathrm{u}}\right)$ were evaluated (Eqn $\left.10-13\right)$ using the methods described by Audu, Khuswaha, Pradhan [25,26]. Percentage seed damage $\left(\mathrm{S}_{\mathrm{d}}\right)$, shelling efficiency $\left(\eta_{\mathrm{e}}\right)$, machine capacity $\left(\mathrm{C}_{\mathrm{m}}\right)$ and throughput capacity $\left(C_{t}\right)$ were calculated using equations $(14-17)$. Each of these tests was done in triplicates at each moisture levels.

$$
\begin{aligned}
& \eta_{s}=\mathrm{N} 1 / \mathrm{NO} \times \mathrm{tT} 100 \\
& \eta_{b}=\mathrm{N} 2 / \mathrm{N} 0 \times 100 \\
& \eta_{p}=\mathrm{N} 3 / \mathrm{N} 0 \times 100 \\
& \eta_{u}=\mathrm{N} 4 / \mathrm{N} 0 \times 100 \\
& S_{d}=\mathrm{N} 5+\mathrm{N} 2 / \mathrm{N} 0 \times 100 \\
& \eta_{e}=\mathrm{N} 1+\mathrm{N} 2 / \mathrm{NO} \\
& C_{m}=M_{s} / \mathrm{T} \\
& C_{t}=M / T
\end{aligned}
$$

where; $C_{t}=$ Throughput capacity $(\mathrm{kg} / \mathrm{h}) ; \mathrm{M}_{\mathrm{f}}=$ Mass of seed fed into the machine $(\mathrm{kg}) ; \mathrm{T}=$ Time taken to complete the operation (h); $\mathrm{C}_{\mathrm{m}}=$ Machine capacity $(\mathrm{kg} / \mathrm{h}) ; \mathrm{M}_{\mathrm{s}}=$ Mass of seed shelled $(\mathrm{kg}) ; \mathrm{T}=$ Time taken to complete the operation (h).

\section{Results and Discussion}

\section{Effect of seed moisture content and shelling speed}

Table 2 shows the shelling characteristics and results of the shelling at different moisture contents and shelling speeds. The performance indicators varied at different shelling speeds and moisture contents. Using equation. 8, the maximum percentage of shelled-unbroken seeds obtained was $61.22 \pm 1.20 \%$ at a seed moisture content of $18.32 \%$ (d,b.) and shelling speed of $1500 \mathrm{rpm}$, while the minimum percentage of shelled-unbroken seeds obtained were $11.49 \pm 0.70 \%$ at shelling speed of $2500 \mathrm{rpm}$ and at a moisture content of $6.99 \%$ (d.b). This is attributed to the brittleness of the seeds at lower moisture contents, which makes them susceptible to mechanical damage. A similar trend was also observed for the percentage of shelled-broken seeds, evaluated using equation 11 , with the highest value of $58.51 \pm 1.57 \%$ at $2500 \mathrm{rpm}$ and $6.99 \%$ (d.b) moisture content, while the lowest $15.13 \pm 0.02 \%$, the lowest was obtained at shelling speed of $1500 \mathrm{rpm}$ and $18.32 \%$ (d.b) moisture content. From the results obtained, it can also be observed that percentage of seed shelled (unbroken) increased with increase in

\begin{tabular}{|c|c|c|c|c|c|c|}
\hline $\begin{array}{l}\text { Moisture content, } \\
\text { d.b (\%) }\end{array}$ & $\begin{array}{l}\text { Shelling speed } \\
(\mathrm{rpm})\end{array}$ & $\begin{array}{l}\text { Percentage of shelled- } \\
\text { unbroken seed, } \eta_{s}(\%)\end{array}$ & $\begin{array}{l}\text { Percentage of shelled- } \\
\text { broken seeds, } \eta_{b}(\%)\end{array}$ & $\begin{array}{l}\text { Percentage of partially } \\
\text { shelled seeds, } \eta_{p}(\%)\end{array}$ & $\begin{array}{l}\text { Percentage of unshelled } \\
\text { seeds, } \eta_{u}(\%)\end{array}$ & Time taken (hr) \\
\hline 6.99 & $\begin{array}{l}1500 \\
2500\end{array}$ & $\begin{array}{l}20.01 \pm 0.16 \\
11.49 \pm 0.70\end{array}$ & $\begin{array}{l}53.09 \pm 0.20 \\
58.51 \pm 1.07\end{array}$ & $\begin{array}{l}8.80 \pm 0.11 \\
10.32 \pm 0.39\end{array}$ & $\begin{array}{l}5.62 \pm 0.93 \\
9.41 \pm 1.30\end{array}$ & $\begin{array}{l}0.10 \pm 0.52 \\
0.07 \pm 0.06\end{array}$ \\
\hline 11.90 & $\begin{array}{l}1500 \\
2500\end{array}$ & $\begin{array}{l}47.29 \pm 0.09 \\
30.94 \pm 0.26\end{array}$ & $\begin{array}{l}25.93 \pm 0.83 \\
40.00 \pm 0.60\end{array}$ & $\begin{array}{l}7.60 \pm 0.18 \\
9.81 \pm 0.72\end{array}$ & $\begin{array}{l}3.90 \pm 0.86 \\
9.41 \pm 2.29\end{array}$ & $\begin{array}{l}0.10 \pm 0.18 \\
0.08 \pm 0.65\end{array}$ \\
\hline 18.32 & $\begin{array}{l}1500 \\
2500\end{array}$ & $\begin{array}{l}61.22 \pm 0.20 \\
32.73 \pm 0.31\end{array}$ & $\begin{array}{l}15.13 \pm 0.02 \\
42.47 \pm 0.17\end{array}$ & $\begin{array}{l}7.49 \pm 0.60 \\
6.44 \pm 0.09\end{array}$ & $\begin{array}{l}3.30 \pm 0.47 \\
3.92 \pm 0.22\end{array}$ & $\begin{array}{l}0.10 \pm 0.36 \\
0.08 \pm 0.01\end{array}$ \\
\hline
\end{tabular}
moisture contents, irrespective of shelling speeds. This shows similar result with the work of Shittu, where increased shelled seeds were obtained with increase in moisture contents. Increase in shelling speeds was also reported to affect the rate of shelling. Higher speeds reduced shelling time, irrespective of the seed moisture contents.

\begin{tabular}{|c|c|}
\hline Variables & Value \\
\hline Seed moisture content, d.b (\%) & $6.99,11.90,18.32$ \\
\hline Shelling speeds (rpm) & 1500,2500 \\
\hline Performance indicators & Shelling efficiency, percentage seed damage \\
\hline
\end{tabular}

Table 1: Variables used for the experiment.

Table 2: Performance of the melon sheller at different variables. 


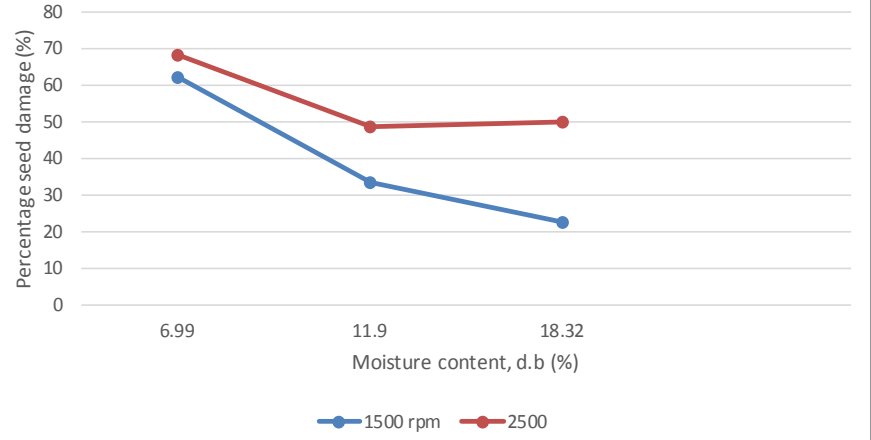

Figure 3: Effect of moisture content and shelling speed on percentage seed damage.

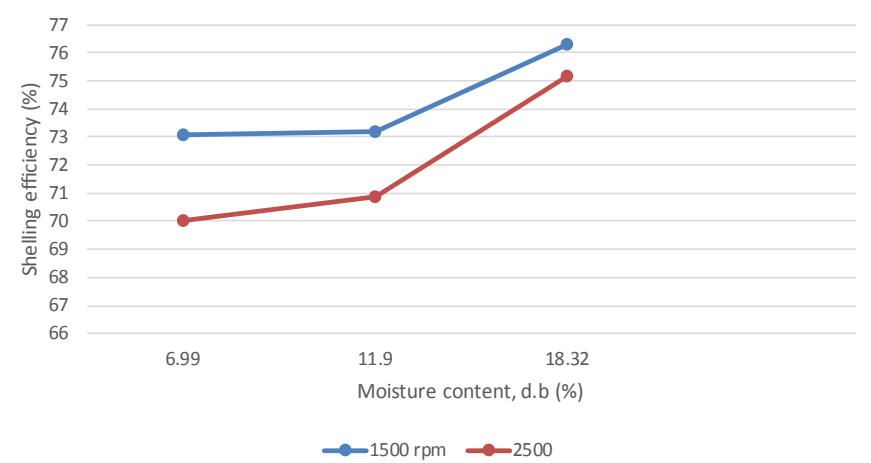

Figure 4: EEffect of moisture content and shelling speed on shelling efficiency.

\section{Percentage seed damage}

The percentage seed damage $\left(\mathrm{S}_{\mathrm{d}}\right)$ was evaluated using equation 14 . Figure 3 represents the effect of shelling speed and moisture content on percentage seed damage. The highest seed damage obtained at 1500 rpm was $61.90 \%$ at $6.99 \%$ (d.b) moisture content and the least value of $22.60 \%$ at $18.32 \%$ (d.b) moisture content at the same shelling speed. A different trend was however observed at shelling speed of $2500 \mathrm{rpm}$. While a higher percentage seed damage of $68.10 \%$ was obtained at a seed moisture content of $6.99 \%$ (d.b), the least seed damage of $48.80 \%$ was rather obtained at moisture content of $11.90 \%$ (d.b). An increase in mechanical seed damage was also generally observed to occur with a succeeding decrease in moisture content. This is also in agreement with the finding of James, which reported an increase in the damage of melon seeds with a consequent increase in speed. This is credited to the increase dryness of the seed and is also ascribed to the relative increase of impact force that resulted from increase in speed [27].

\section{Shelling efficiency}

The shelling efficiency of the machine $\left(\eta_{\mathrm{e}}\right)$ was evaluated using equation 15. The effect of shelling speed and moisture on shelling efficiency is presented in Figure 4. This was observed to increase with an increase in seed moisture content from $73.10 \%$ to $76.30 \%$ and $70 \%$ to $75.20 \%$ at $1500 \mathrm{rpm}$ and $2500 \mathrm{rpm}$ respectively. This trend corresponds to the findings of Audu, reported an increase in efficiency of dehulling locust bean with an increase in moisture content.

\section{Machine and throughput capacity}

Using equations 16 and 17, the machine and throughput capacity were calculated as 7.95 and $9.56 \mathrm{~kg} / \mathrm{h}$ respectively, based on the highest shelling efficiency values. The machine capacity obtained is however, relatively low as compared values obtained by James and Shittu $[11,15]$. This can be attributed to smaller size of hopper used in this study.

\section{Conclusion}

A gasoline powered melon seed sheller was designed constructed and evaluated in this study. Results obtained showed that the machine can effectively shell melon seeds and that seed moisture contents and the speed of the shelling machine affected the performance indicators. The shelling efficiency increases with an increase in moisture content and decrease in shelling speed, with an optimum moisture content and shelling speed of $18.32 \%$ and $1500 \mathrm{rpm}$ respectively. The machine is user friendly, does not require skilled labor and the incessant power outages prevalent in developing countries such as Nigeria, and does not affect its use. Due to its relative cheaper cost of production, it can effectively address the need of rural dwellers as well as small and medium scale farmers in developing countries, and the difficulties associated with customary method of shelling melon will reduced. Further work should be done using other moisture contents and speed combinations to determine the optimum shelling condition for the sheller. The capacity of the hopper also needs to be increased to upscale the machine capacity.

\section{References}

1. Bankole SA, Adenusi AA, Lawal OS, Adesanya OO (2010) Occurrence of aflatoxin $B_{1}$ in food products derivable from 'egusi' melon seeds consumed in southwestern Nigeria. Food Control 21: 974-976.

2. Egbe DE, Mayah TF, Ebot EG, Egbe PA, Abraham JP (2015) Performance evaluation and improvement on a melon seed shelling machine. World Journal of Agricultural Sciences and Engineering 1: 1-10.

3. Aguayo E, Escalona VH, Artes E (2004) Metabolic behavior and quality changes of whole and fresh processed melon. Journal of Food Science 69: 148-155.

4. Ogbonna PE, Obi IU (2007) Performance of genotypes in crosses of egus melon. Journal of Agriculture, Food, Environment and Extension 6: 1-8.

5. Sabo H, Sadou H, Amoukou IA, Alma MM, Sidikou RS, et al. (2015) Determination and comparison of the amino acid composition of seventeen Lagenaria siceraria varieties and one variety of Citrullus colocynthis seed flours. Pakistan Journal of Nutrition 14: 100-106.

6. Abaelu AM, Makinde MA, Akinrimisi EO (1979) Melon (egusi) seed protein 1: Study of amino acid composition of defatted meal. Nutritional Reports International 20: 605-613.

7. Achu MB, Fokou E, Tchiegang C, Fotso M, Tchouanguep FM (2005) Nutritive value of some Cucurbitaceae oilseeds from different regions in Cameroon. African Journal of Biotechnology 4: 1329-1334

8. Olaniyi JO (2008) Growth and seed yield response of egusi melon to nitrogen and phosphorus fertilizers application. American-Eurasian Journal of Sustainable Agriculture 2: 255-260.

9. Gorski SF (1985) Melons in detecting mineral nutrient deficiencies in tropical and temperate crops. Journal of Plant Nutrition 8: 283-291.

10. Bankole SA, Osho A, Joda AO, Enikuomehin OA (2005) Effect of drying method on the quality and storability of 'egusi' melon seeds (Colocynthis citrullus L.). African Journal of Biotechnology 4: 799-803.

11. Shittu SK, Ndrika VIO (2012) Development and performance tests of a melon (egusi) seed shelling machine. Agricultural Engineering International 14: 1-11.

12. Nwakire JN, Ugwuishiwu BO, Ohagwu CJ (2011) Design, construction and performance analysis of a maize thresher for rural dweller. Nigerian Journal of Technology 30: 49-51.

13. Adekunle AS, Ohijeagbon IO, Olusegun HD (2009) Development and performance evaluation of manually and motorized operated melon shelling machine using impact technique. Journal of Engineering Science and Technology Review 2: 12-17.

14. Pradhan RC, Naik SN, Bhatnagar N, Vijay VK (2010) Design, development 
Citation: Sobowale SS, Adebiyi JA, Adebo OA (2015) Design, Construction and Performance Evaluation of a Melon Seeds Sheller. J Food Process Technol 6: 463. doi:10.4172/2157-7110.1000463

Page 5 of 5

and testing of hand-operated decorticator for Jatropha fruit. Applied Energy 87: $762-768$

15. James KM, Umogbai V, Itodo IN (2011) Development and evaluation of a melon shelling and cleaning machine. Journal of Emerging Trends in Engineering and Applied Sciences 2: 383-388.

16. Nkakini SO, Ayotamuno MJ, Maeba GPD, Ogaji SOT, Probert SD (2007) Manually powered continuous flow maize sheller. Applied Energy 84: 1175-86.

17. Fashina AB (1971) The design and development of a melon sheller. University of Ife, Nigeria.

18. Odigboh EU (1979) Impact egusi shelling machine. Transaction of the ASAE 22: $1264-1269$

19. Fadamoro I (1999) Design and Construction of a manually operated melon sheller. University of Ilorin, Nigeria.

20. Davies RM (2010) Engineering properties of three varieties of melon seeds as potentials for development of melon processing machines. Advance Journal of Food Science and Technology 2: 63-66.
21. William LA (1953) Mechanical Power Transmission Manual. Conover-Mast Publ. New York. NY, USA.

22. Hannah J, Stephens RC (1980) Mechanics of Machines. Edward Arnold Publishers Ltd. London.

23. Khurmi, RS, Gupta JK (2004) Theory of Machines. Eurasia Publishing House, New Delhi, India.

24. Oluwole OO, Adedeji AS (2012) Effect of moisture content and inner drum rotation speed on the shelling performance of a melon sheller. Science and Technology 2: 21-26.

25. Audu I, Oloso A, Umar B (2004) Development of a concentric cylinder locust bean dehuller. Agricultural Engineering International 6: 1-11

26. Khuswaha HL, Srivastava AP, Singh H (2005) Development and performance evaluation of okra seed extractor. Agricultural Engineering International 7: 1-13.

27. Sharma V, Pradhan RC, Naik SN, Bhatnagar N, Singh S (2013) Evaluation of a centrifugal impaction-type decorticator for shelling tung fruits. Industrial Crops and Products 43: 126-131 